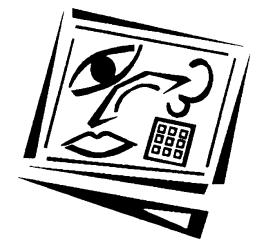

\title{
Understanding student perceptions and motivation towards academic blogs: An exploratory study
}

Liping Deng

Hong Kong Baptist University

\author{
Allan H. K. Yuen \\ The University of Hong Kong
}

\begin{abstract}
The success of academic blogs depends on the participation and engagement of students. Taking an exploratory approach, this study aims to develop a better understanding of the perceptions of student teachers towards academic blogging, and the factors that motivate them to write academic blogs voluntarily. Drawing on data gathered from questionnaires, interviews, and content analysis of blog posts, the study reveals a set of mediating factors in individual, social and academic dimensions, among which students' perceived values of blogs play a critical role. Our findings have methodological and practical implications for researchers and teachers interested in academic blogs, especially for those in the field of teacher education.
\end{abstract}

\section{Introduction}

Web-based technology, with its unprecedented accessibility and interactivity, has been increasingly used to enhance teaching practice and learning experiences. However, in spite of the fact that web-based course management systems have been mainstreamed in the context of higher education (Zastrocky, Harris, \& Lowendahl, 2008), they have been employed more for informative purposes than for interactive purposes (Morgan, 2003; Hamuy \& Galaz, 2010). The emergence of Web 2.0 technology in recent years has attracted a great deal of interest among educators and researchers, especially those who are disenchanted by the first generation of Internet tools that are used mostly for information presentation and broadcasting (Brown \& Adler, 2008). The term 'Web 2.0' has been coined to symbolise a new generation of web software that embraces the power of user participation, collective intelligence, and knowledge sharing (Brown \& Adler, 2008; Harrison \& Barthel, 2009; McLoughlin \& Lee, 2007; O'Reilly, 2007). In the era of Web 2.0, impediments to online participation have less to do with the accessibility of technology, and more to do with users' motivation and interest. In Jenkins' (2006) words, participation gap and uneven motivation constitute the new digital divide. Hence, in a learning environment supported by Web 2.0 technology, students' motivation for online participation and engagement has become an issue of critical importance.

Blogs, often seen as easy-to-update websites with dated entries presented in reverse chronological order (Stefanac, 2006), have become the main venue for self-publishing on the Internet (Wortham, 2007). They are now a well-established and widely recognised form of digital communication and should thus be taken seriously in educational settings (Davies \& Merchant, 2009). There is a growing body of scholarly 
work on the application of blogs in various academic disciplines such as teacher education (Deng \& Yuen, 2011; Hernández-Ramos, 2004; Hourigan \& Murray, 2010; Ray \& Coulter, 2008; Stiler \& Philleo, 2003; Wopereis, Sloep \& Poortman, 2010; Yang, 2009), business (Williams \& Jacobs, 2004), and language learning (Ducate \& Lomicka, 2008; Mompean, 2010). Blogging is acclaimed as a flexible tool that can be used to support both individual and community learning. For individual learners, blogs can foster self-expression and reflective writing (Brescia \& Miller, 2006; Ferdig \& Trammell, 2004; Ray \& Coulter, 2008; Stiler \& Philleo, 2003; Wopereis, Sloep, \& Poortman, 2010; Yang, 2009). For a learning community, blogs can provide an online platform for sharing, networking, communication, and collaborative learning (Dickey, 2004; Du \& Wagner, 2007; Hall \& Davison, 2007; Loving, Schroeder, Kang, Shimek \& Herbert, 2007; Luehmann \& Tinelli, 2008; Ray \& Hocutt, 2006; Williams \& Jacobs, 2004). Deng and Yuen (2011) also proposed a framework for the educational affordances of blogs that included both individual and social dimensions. However, the educational affordances of a technology are not a set of fixed attributes, but describe the relationship between the properties of an educational technology and the characteristics of the learners who use it (Kirschner, 2002). Therefore, the successful use of blogs is also contingent on learner-related or contextual factors.

This study aims to develop a better understanding of the perceptions of student teachers towards academic blogging and the factors that motivated them to write academic blogs voluntarily. Here, academic blogs refer to blogs that are written purely or primarily for learning purposes, in contrast to personal blogs that are written mostly for personal or social purposes. Motivation, in a general sense, can be defined as the causes that engage people in an activity (Wakefield, 1996). When it comes to information technology, the technology acceptance model is often used to examine how the intention of using a technology is associated with users' perceived usefulness and perceived ease of use (see Davis, 1989). Hence this study takes a student-centred approach to investigate student perceptions and how their perceptions are associated with the engagement with academic blogging. A central conviction underlying this inquiry is that a better comprehension of students' perceptions and motivation for blogging can allow teachers and researchers to avoid pitfalls and to better exploit the pedagogical affordances of blogs. The following section will give an account of recent research studies that centre on bloggers' perceptions and motivation. Given the limited number of studies addressing the motivation issues of blogging, we include the scholarly work in fields other than educational blogging.

\section{Review of related studies}

In an early conceptual work on blogs, Blood (2002) identified four main purposes in maintaining a blog: self-expression, keeping in touch, information sharing and reputation building. As one of the early empirical studies on the topic, Nardi, Shiano, Gumbrecht and Swartz (2004) interviewed 23 bloggers and discovered five major reasons for writing blogs: to document life, provide commentary and opinions, express emotions, articulate ideas, and form or maintain a community forum. In another paper on a similar theme, Nardi, Schiano and Gumbrecht (2004) added that bloggers were also interested in updating others on their lives, and seeking others' opinions or feedback. Trevino (2005) interviewed 14 college students and provided some interesting insights on why they started blogging and continued doing so. Most students started blogging out of extrinsic motivation when they saw someone around them blogging, and they continued to blog in order to document their lives, express 
themselves, and keep others updated on the daily events in their lives. It was also noted that not all the bloggers wanted feedback and attention from their audience: some just blogged for themselves.

Another strand of research takes a quantitative approach to the issue of motivation for blogging, yet with varying focus and theoretical underpinning. One line of such work focuses on the impact of personal traits. Miura and Yamashita (2007) sought to clarify the psychological and social processes that motivated Japanese bloggers to continue writing personal blogs. They identified two psychological traits - self-consciousness and reassurance-seeking - that directly influenced the perceived benefits of blogging. Bloggers with high levels of self-consciousness tended to blog for the sake of experience documentation and emotional release, while bloggers with high levels of reassurance-seeking tended to use blogs to communicate with others and maintain relationships.

In a similar vein, Guadagno, Okdie and Eno (2008) examined the relationship between personality and motivation for blogging through surveying more than 300 undergraduate students. Out of the five personality dimensions (extraversion, agreeableness, conscientiousness, neuroticism, and openness), they found that neuroticism and openness were influential motivating factors, in that those students who were open to new experiences or afflicted by anxiety, worry, or nervousness tended to blog more. Building on the work of Guadagno and associates (2008), Wang, Lin, and Liao (2012) probed into how individual differences among university students affected their intention to blog through the mediation of perceived enjoyment (PE). Other than the five dimensions of personality, they included computer self-efficacy (CSE), and personal innovation in information technology (PIIT) as the factors under investigation. Interestingly, Wang and colleagues yielded quite different results from the study of Guadagno, Okdie and Eno (2008). Three personality traits - extraversion, agreeableness, conscientiousness - and PIIT were found to have a significant influence on PE, which in turn significantly affected students' intention to blog. Stefanone and Jang (2007) had a similar research interest on the impact of personality traits on blogging. However, they proposed that study on the motivation to blog should be situated in bloggers' social contexts, and they thus brought in personal network size as another mediator for the use of blogs. They surveyed 154 individual bloggers on blogger.com and revealed that those high on extraversion and self-disclosure had a bigger strong network size, which in turn positively influenced their use of blogs for relationship maintenance.

Another line of quantitative work is rooted in technology adoption models. Drawing on the theories of technology acceptance, knowledge sharing and social influence, Hsu and Lin (2008) investigated the intention to blog by surveying 212 bloggers. They reported five significant determinants for blogging: perceived ease of use, perceived enjoyment, altruism, reputation, and identification with a blogging community. With the uses and gratifications perspective, Hollenbaugh (2011) examined the motives for writing personal journal blogs using data collected from nearly 300 active bloggers. The leading motives for blogging, they reported, were to record/organise thoughts and feelings, share information to help or inform others, keep social connections, and seek feedback from others.

Drawing on the perspectives of intrinsic and extrinsic motivation from cognitive psychology, Ekdale, Namkoong, Fung and Perlmutter (2010) focused on a specific type of blogger - top American political bloggers. Through a survey of 66 bloggers, they 
found an interesting trajectory of motivation evolvement over time. The intrinsic motivations - "to let off steam", "to formulate new ideas", and "to keep track of thoughts" - were the strongest initial motivations. Over time, the bloggers became increasingly aware of the external rewards - "to provide alternative perspectives", "to inform people", and "to influence public opinion"; hence, the extrinsic motivators became greater reasons for their sustained motivation.

The majority of the aforementioned studies were interested in either the general blogger population (e.g. Hsu \& Lin, 2008; Nardi, Shiano, Gumbrecht \& Swartz, 2004; Stefanone \& Jang, 2007) or blogging as personal or leisure-related activities. Although three studies - Trevino (2005), Guadagno, Okdie and Eno (2008), and Wang, Lin, and Liao (2012) - involved university students, their focus was not on blogging for learning purposes. In this respect, the studies by Kerawalla, Minocha, Kirkup and Conole (2008, 2009) are the only empirical work, at least to our knowledge, that centred on the participation of students in academic blogs. The first phase of their study identified five types of blogging behaviour: blogging avoidance, resource network building, support network building, self-sufficient blogging, and blogging in order to complete the suggested course activities (Kerawalla, et al., 2008). At the same time, the study revealed four critical factors that mediated students' blogging behaviour: (1) perceptions of, and need for, an audience; (2) perceptions of, and need for, community; (3) comments from other students; and (4) presentation style of their blogs. The second phase of the study reported three additional factors in effect: (1) perceived distinct role of blogging compared to other e-learning tools; (2) functionality of blogging; and (3) course design elements such as clarified purposes, guidance on how to blog, and facilitation for socialisation and collaboration (Kerawalla, et al., 2009).

Within the growing body of literature on the educational use of blogs, little attention has been paid to the experience, perceptions, and motivation of students who engage in academic blogging (Kerawalla, et al., 2008; Xie \& Sharma, 2005). Herring, Scheidt, Wright and Bonus (2005) identified three blog genres: personal journals, filter blogs, and knowledge blogs (K-logs). The personal journal blogs were a highly individualistic or even intimate form of self-expression; while the K-logs resembled learning or research journals that were used to record learning processes or artifacts. The academic blogs in our study can be viewed as K-logs, which are significantly different from personal journal blogs. Thus, students' motivation for academic blogging warrants special attention. However, in many cases, academic blogging is required and counted as a part of formal assessment. The conditions or factors that facilitate or inhibit students' engagement with blogging are either ignored or difficult to discern. To address these research gaps, we probe into the perceptions of two groups of student teachers who took part in academic blogging and seek to reveal the underlying reasons for their voluntary blogging.

\section{Methods}

\section{Study context}

The study included two classes (Classes A and B) of fourth year students from the Bachelor of Education program majoring in English language education at a university in Hong Kong. The two classes attended the same core course - Professional Studies III - taught by the same instructor in two consecutive academic years. Integrated into the course was an eight-week teaching practice (TP) during which the student teachers 
were placed in different schools across Hong Kong, either individually or in pairs. Voluntary academic blogging was introduced to connect the geographically dispersed class and foster sharing and support. Originally, there were 15 students in Class A and 22 in Class B. Before the TP, we administered paper-based questionnaires to gather information regarding students' technical proficiency, familiarity with blogs, and their previous TP experience. 13 students in Class A and 19 in Class B took the questionnaires. The results showed that the student teachers in both classes were quite technology-proficient as the majority of them had prior experience with online forums and Instant Messenger. They were also familiar with blogs since 11 students in Class A $(69 \%)$ and 13 in Class B $(68 \%)$ had their own personal blogs. The actual number of students who participated in academic blogging was 13 for both classes.

\section{Design of academic blogging activities}

In spite of the voluntary nature of academic blogging, the researchers and the instructor made collaborative efforts to design blogging activities, motivate, and support the students. Academic blogs were promoted as a less formal means by which the student teachers could document their TP experience, relieve emotional tensions, and reflect on their teaching practice. The students were given general guidelines such as posting once a week and encouraged to read the blogs of their peers and post comments. Although the general structure and guidelines of blogging were similar for both classes, some changes were made for Class B based on the insights gleaned and lessons learned from Class A. For example, we explicitly encouraged Class B to: (1) move beyond emotional outburst and engage in reflection; and (2) document their teaching ideas and activities in more detail so that their peers could learn from them. The assessment component and its link with blogging activities also underwent modification. The students in Class A were expected to write three reflective essays during TP and encouraged to share their reflective essays via blogs. The assignment for Class B, on the other hand, was an action research report, and the students could include their blogs in the appendix of the assignment in order to provide rich background information and evidence of their reflection during practice and on practice.

In addition to the design of blogging activities, the other important task was to construct a blogging environment. Since the majority of the student teachers already had their personal blogs on Xanga (http:/ / www.xanga.com/) prior to the study, they were encouraged to continue using their existing accounts or set up new accounts for academic purposes. An online community space was created as the central place where links to blogs belonging to individual students were aggregated. The instructor also utilised this space as a bulletin board to send out messages to the student teachers. One of the researchers acted as the blog facilitator responsible for maintaining the community space, monitoring students' blogging, and providing support when necessary. She also posted weekly summaries of students' blogs on the community space and occasionally commented on their blogs.

\section{Data collection and analysis}

Adopting an exploratory qualitative approach, the study used questionnaires, interviews, and students' blogs as the main sources of data. For each group of students, two paper-based questionnaires in English were administered: one before and the other after the TP. The post-TP questionnaires aimed to probe into student perceptions 
and the factors that affected their engagement with academic blogging (See Appendix). The construction of the questionnaires was informed by the researchers' observation, related literature, and the instructor's feedback. The questions were mostly 5-point Likert-type questions ( 1 for strongly disagree, 5 for strongly agree). Two experts in educational technology and teacher education were invited to examine and critique the questionnaires and minor changes were made based on the feedback received. The paper-based questionnaires were distributed and gathered at the last session of the course and 13 students in Class A and 19 students in Class B answered the questionnaires.

To deepen our understanding of the students' motivation and perceptions, we conducted individual interviews with students who were either self-selected or purposefully chosen. First, students were invited to volunteer for the interview. Based on the responses, individual students were selected in an effort to ensure the variance of gender and the level of participation. The eight participants included two males and six females who had various levels of participation in academic blogs. The interview questions consisted of a set of general questions (e.g. What made you start to write academic blogs? What do you see as the values of academic blogging?) and tailormade questions based on the students' blogging performance. For example, for a student who was active in blogging first but stopped blogging later on was asked about the reasons behind it. The interviews were conducted in English and intended to last from 30 to 45 minutes. The interviews were recorded, transcribed and analysed with NVivo (http:/ / www.qsrinternational.com/). The analysis of interview data first adopted the open coding approach that allowed categories to emerge from the data. These categories were then refined and restructured in accordance with related literature.

The contents of students' blogs became another valuable source of data that could serve the dual purpose of verifying and discovering. Through looking into what the student teachers actually wrote about, we would be able to triangulate the selfreported data obtained through questionnaires and interviews, and extend our understanding and insights into blogging motivation. To this end, the content of each blog post was extracted and recorded in a database. The coding procedure was guided by a combination of predetermined categories and emerging themes (Creswell, 2009). A preliminary set of blog themes was distilled from the relevant literature, and remained open for revision based on themes emerging during the coding process. The blogging motivations reported by the literature were synthesised and refined to fit our study context, which resulted in five preliminary categories: documentation of experience, keeping others updated, expressions of feelings, expressions of thoughts or reflection, and sharing teaching ideas. As the analysis of the blogs proceeded, one more category - "seeking help" - was identified and added to the blog themes (See Table 1).

Table 1: Coding scheme for blog themes

\begin{tabular}{|l|l|}
\hline \multicolumn{1}{|c|}{ Themes } & \multicolumn{1}{c|}{ Definition } \\
\hline Documentation of experience & Describing what happened \\
\hline Keeping others updated & Describing what happened with social cues \\
\hline Sharing teaching ideas & $\begin{array}{l}\text { Giving detailed description of teaching strategies } \\
\text { or learning activities }\end{array}$ \\
\hline Expressions of feelings & Expressing personal feelings \\
\hline Expressions of thoughts or reflection & Expressing thoughts or reflective thinking \\
\hline Seeking help or advice & $\begin{array}{l}\text { Asking questions or explicitly seeking help or } \\
\text { advice from others }\end{array}$ \\
\hline
\end{tabular}


The "documentation of experience" type of blogs usually gave a simple account of daily events. To a large extent, this type of blog resembled a personal diary or journal that was written mostly for oneself. The theme of "keeping others updated" was very similar to "documentation of experience" in terms of contents; the main difference resided in the social cues that included addressing others or the group (e.g. we, our), salutations (e.g. "hi, all"), expressing appreciation (e.g. "Thanks my dear classmates), asking questions or seeking help (e.g. "How can I solve this?") (see Rourke, Anderson, Garrison \& Archer, 1999). These social cues signified that the blog authors kept their audience in mind, and blogs were written to keep others informed of what had happened to them.

Another theme - "sharing teaching ideas" - also gave an account of what was going on during TP, but at a different level of depth. Blogs of this type gave detailed descriptions of teaching strategies or activities designed for a specific topic or unit. Sometimes, authors also included the reactions of their students or feedback they had received. Intentionally or unintentionally, this type of blog allowed for the sharing of teaching ideas that might inspire fellow students. In contrast to the self-documentation type of blogs, the posts manifesting "expressions of thoughts or reflection" were regarded as academic. To assist our evaluation of the reflective elements, several criteria for reflective work advanced by other scholars were put into use. The reflective attributes included the attempts to explain or justify (Hatton \& Smith, 1995), to link practices with teacher competences, beliefs, and identity (Korthagen \& Vasalos, 2005), and to contemplate personal, professional or social problems associated with teaching (Surbeck, Han \& Moyer, 1991). Additionally, the posts characterised by "expressions of feelings" contained conventional expressions of emotions (e.g. "I am feeling so bad") and/or CMC-specific ways of emotional expressions such as the use of emoticons, repetitious punctuation (e.g. "It's really hard and exhausting!!!!"), and conspicuous capitalisation (e.g. "I SURVIVE!") (Rourke et al., 1999). For the category of "seeking help or advice", we only included the posts in which the bloggers described their problems and explicitly invited input, suggestions or solutions (e.g. "How can I solve this?").

Adopting a similar approach to that of Herring, Scheidt, Wright and Bonus (2005), we sought to code the overall purpose of each blog post, which involved the evaluation of the salient theme. However, the above-mentioned categories were not mutually exclusive since some posts could have more than one focus or agenda. A total number of 139 blog entries were analysed, of which 15\% in Class A and 31\% in Class B were coded with two themes. Twenty posts from each class were randomly selected and coded independently by one of the researchers and a research assistant, and the resulting inter-rater agreement (kappa) was 0.86 .

\section{Results}

Altogether, there were 26 blogging students in two classes (13 in each class), who produced a total number of 139 blog posts (64 in Class A, 75 in Class B). On average, each blogging student posted 5.5 times over an eight-week period, which was less than once a week. Moreover, there was a large variation in the number of blogs written by each student, especially those of Class B as shown in Table 2. This points to a heightened need to understand the reasons behind the varying levels of engagement with academic blogging. 
Table 2: Descriptive data for blog output

\begin{tabular}{|l|c|c|c|c|c|c|}
\hline & Min & Max & Mean & SD & Skewness & Kurtosis \\
\hline Class A & 2 & 11 & 5 & 2.345 & 1.191 & 2.828 \\
\hline Class B & 1 & 34 & 6 & 9.238 & 2.705 & 7.865 \\
\hline
\end{tabular}

The data collected revealed a set of motivating factors for academic blogging that can be grouped under three dimensions: individual, social, and academic. The presentation of our findings will be structured accordingly. One thing worth noting is that the categorisation of the factors is by no means arbitrary, but a way to help present and make sense of the findings.

\section{Individual dimension}

In the post-TP questionnaires, we asked the blogging students what drove them to write academic blogs. As shown in Table 3, many student teachers wrote academic blogs out of the desire to document their TP experience $(77 \%$ in Class A and $85 \%$ in Class B in agreement), express their feelings or relieve stress (62\% in Class A and 77\% in Class B in agreement). Through the interviews, more reasons for blogging surfaced. The most active blogger remarked that blogging had been a habit of hers for a long time: "I just love to write blogs to record my experience"; so for her, writing academic blogs was an extension of a long held habit.

Table 3: Reasons for blogging from post-TP questionnaires

\begin{tabular}{|c|c|c|c|c|c|c|c|c|}
\hline \multirow[b]{2}{*}{ Reasons for blogging } & \multicolumn{4}{|c|}{ Class A } & \multicolumn{4}{|c|}{ Class B } \\
\hline & $\begin{array}{c}\text { SA \& A } \\
(\%)\end{array}$ & $\begin{array}{l}\text { Neutral } \\
(\%)\end{array}$ & $\begin{array}{c}\mathrm{D} \& \text { SD } \\
(\%)\end{array}$ & M & $\begin{array}{c}\text { SA \& A } \\
(\%)\end{array}$ & $\begin{array}{l}\text { Neutral } \\
(\%)\end{array}$ & $\begin{array}{c}\mathrm{D} \& \mathrm{SD} \\
(\%)\end{array}$ & $\mathrm{M}$ \\
\hline Document experiences & 77 & 15.4 & 7.7 & 4.00 & 84.6 & 15.4 & 0 & 4.2 \\
\hline $\begin{array}{l}\text { Express feelings/ relieve } \\
\text { stress }\end{array}$ & 61.6 & 7.7 & 30.8 & 3.54 & 76.9 & 23.1 & 0 & 4 \\
\hline $\begin{array}{l}\text { Share teaching ideas } \\
\text { with peers }\end{array}$ & 77 & 15.4 & 7.7 & 4.00 & 76.9 & 23.1 & 0 & 4 \\
\hline Keep others updated & 92.3 & 7.7 & 0 & 4.31 & 61.5 & 38.5 & 0 & 3.6 \\
\hline $\begin{array}{l}\text { Other classmates are } \\
\text { blogging }\end{array}$ & 61.6 & 38.5 & 0 & 3.77 & 30.8 & 38.4 & 30.8 & 2.9 \\
\hline $\begin{array}{l}\text { The instructor urged us } \\
\text { to blog }\end{array}$ & 38.5 & 38.5 & 23.1 & 3.00 & 38.5 & 53.8 & 7.7 & 3.2 \\
\hline
\end{tabular}

Additionally, we analysed the contents of student blogs in an effort to discern what the student teachers wrote about and for what purposes. As Table 4 indicates, a popular theme found in nearly half of the blogs was the articulation of thoughts or reflection on teaching practice. A good example of this type of entry reads:

$$
\begin{aligned}
& \text { You can't separate peace from freedom because no one can be at peace unless he has } \\
& \text { his freedom. --- Malcolm X (1925-1965) This quote is thought-provoking. To what } \\
& \text { extent can one enjoy freedom? Given the situation that our school has NO school rules, } \\
& \text { students here enjoy their lives with no boundaries. If the school is encouraging a } \\
& \text { trusting and positive environment, there should be a set of believes or guiding } \\
& \text { principles, ... Without bearing a common faith in our minds, it seems hard to find } \\
& \text { "peace" in a community. }
\end{aligned}
$$

In contrast, the self-documentation type of posts, characterised by the absence of social cues or reflective elements, was comparatively rare. There were only two entries in 
Class A that fell into this category. In Class B, although one quarter of the blog entries were coded as self-documentation, all of them were written by the most productive blogger. As a regular blogger, she wrote an entry every day during TP, and her blogs were a mixture of writing for herself and writing for others. The purely selfdocumentation type of posts was usually rather short and simply recorded daily happenings as in this example:

Although I don't have any lessons on Mondays, it's still a productive day. I prepared for oral lesson about agreeing and disagreeing in group discussion and one of the reading strategies, drawing timelines, in the morning. I had a great lunch meeting. It's about teaching and learning English through social issues.

Other than that, $36 \%$ of the blogs in Class A and $13 \%$ in Class B had emotional outbursts as the overriding theme. In these cases, the student teachers simply wrote blogs to "let off steam" as illustrated by this entry:

hectic life starts again... i feel like i am very vulnerable now and i want to throw up. i have no idea why i feel that. suddenly i feel sick of having tp.

Table 4: Results of blog theme analysis (individual dimension)

\begin{tabular}{|l|c|c|}
\hline \multicolumn{1}{|c|}{ Themes } & Class A (n=64) & Class B (n=75) \\
\hline Expressions of thoughts or reflection & $28(44 \%)$ & $32(43 \%)$ \\
\hline Expressions of feelings & $23(36 \%)$ & $10(13 \%)$ \\
\hline Documentation of experience & $2(3 \%)$ & $19(25 \%)$ \\
\hline
\end{tabular}

\section{Social dimension}

The social dimension constituted another important driving force for students' blogging. The questionnaire data revealed that the student teachers were drawn to blogging out of the desire to keep other classmates updated (92\% in Class A and 62\% in Class B in agreement), and to exchange teaching ideas (77\% in both Classes in agreement). More student teachers in Class A were inclined to blog under the social influence of fellow students, with $62 \%$ of respondents acknowledging that they wrote blogs because other classmates did so.

Moreover, several students highlighted the value of a nurturing social environment during interviews. When asked why they had started academic blogging, several students acknowledged the impulse to share with their peers, as one student described, "I do have a lot of things to share, like teaching ideas. I myself find it interesting, and I think they might want to hear about it." Another underscored the importance of group cohesion by saying, "the closer we are, the more willing we are to share our experience with other classmates." Another interviewee pointed out that it was social influence that had prompted her to start academic blogging. She said:

Since some of my classmates started sharing their teaching practice, so I think I might share mine as well. I do read their blogs and sometimes I got teaching ideas from it. So I thought I might share mine as well. It will be selfish of me just to read and not share mine.

The social impetus for blogging was also recorded in their blogs. The following excerpt depicts how a student who was not very interested in blogging originally changed her perspective under the social influence. 
Hey everyone.........I dunno anything about xanga since I am actually not really fond of this stuff!!!! However, in order to communicate with all my colleagues, here I am to share my days in the TP school!!!

The analysis of students' blogs also confirmed the social motives for blogging. As shown in Table 5, around one quarter of the posts in Class A and one fifth in Class B were intended to keep fellow students updated. This type of post gave readers a clear sense that bloggers were talking to them. A case in point might be the entry that started:

Since I was absent on the mid-tp review day. Here is my brief report about my teaching practicum so far. Hope you enjoy reading it!!

Table 5: Results of blog theme analysis (social dimension)

\begin{tabular}{|l|c|c|}
\hline \multicolumn{1}{|c|}{ Themes } & Class A $(\mathrm{n}=64)$ & Class B $(\mathrm{n}=75)$ \\
\hline Keep others updated & $17(27 \%)$ & $13(17 \%)$ \\
\hline Sharing teaching ideas & $2(3 \%)$ & $20(27 \%)$ \\
\hline Seeking help & $2(3 \%)$ & $4(5 \%)$ \\
\hline
\end{tabular}

Although the majority of students in Class A showed their interest in sharing teaching ideas with their peers through the questionnaires, the content analysis of their blogs revealed only two posts of such a nature. On the other hand, $27 \%$ of the posts from Class B served this purpose. In one such entry, a student reported in detail two games she had brought into her class and ended the entry by saying, "I think the 2 games make answer-checking more lively and less boring. You may try them out next time." Another student also offered a detailed account of the instructional activities he used in class. Although he did not explicitly invite or prompt others to try out his gaming strategy, several students did adopt it as indicated by the comments posted to his blogs.

The differences between the blogs in the two classes regarding the exchange of teaching ideas and emotional release might be related to the styles of early adopters. It was observed that the early adopters in Class A produced emotionally charged posts at the outset of the TP, while their counterparts in Class B wrote in a more academic and reflective fashion. During the interviews, two interviewees commented on the peer influence on their blogging styles. As one put it, "It's like if people start to do reflection, you will do reflection as well. If people start talking about their feeling, I will talk about my feeling." The other remarked: "after reading the blogs written by other students, they gave me an guideline on what I am going to talk about."

However, even though the student teachers were aware of the social nature of blogging, they seldom used blogs to seek help or ask questions. There were only two entries in Class A and four in Class B in which the student teachers discussed problems encountered and explicitly asked for help. The following excerpt is one example.

I have a question. How do you do your dictation with your students? I had dictation with my students today. Sometimes I just feel that I can never get it right. It's so hard!! All the words are read aloud in fragments and it's difficult to get it correct!!

It was also revealed that fellow students in the immediate social environment could have positive effects on blogging practice. During the interviews, one student described how her TP partner helped her set up a new account on Xanga. As a mature 
student, she was not very familiar with web-based technology, and thus, her TP partner became an important resource to turn to for just-in-time help. On the other hand, interestingly, two students in Class A who were alone in their placement schools turned out to be quite active bloggers. Through their blogs, they expressed their sense of isolation and lack of support, which seemed to serve as an incentive for their blogging. The same scenario was not directly observed in Class B, but was mentioned by two of the interviewees as a potential stimulus for blogging. One student looked back on his Year Two TP experience, during which time he was involved in a major incident, and commented, "it will be good if at that time I had the chance to write reflective blogs for others to give objective comments." The other also remarked that she might be more compelled to write blogs "if the school gave me a lot of problems and I really need a channel to vent my emotions".

\section{Academic dimension}

In our study, various design efforts were made to engage the student teachers in academic blogging. The instructor acted as a cheerleader encouraging students' use of blogs for reflection and sharing. However, due to her busy schedule, she only posted three times on the community space and did not respond to students' blogs. The postTP questionnaires of both classes indicated that less that $40 \%$ of the student teachers perceived the encouragement of the instructor as a valid source of motivation. However, they greatly appreciated her posts, with $92 \%$ in Class A and $74 \%$ in Class B perceiving them as a valuable feature of the community space. In echo with this, a majority of students thought that more involvement on the part of the instructor would enhance their interest in writing academic blogs. $62 \%$ in Class A and $58 \%$ in Class B expressed their desire for more comments or feedback from the instructor, and around $70 \%$ of students in both classes showed they would appreciate more posts from her. The same perspective was also noted in the interviews. Several interviewees looked on the instructor as a very supportive, resourceful, and creative teacher who always encouraged and inspired them. They felt it would be great if they could continue interacting with her through blogs during the TP when they were in real need of guidance and constructive feedback.

Although blogging activities were optional for both classes, the instructor made academic blogging more "visible" in Class B, which contributed to a heightened motivation. The blogging students could attach their blogs to the appendix of their assignments as evidence of their reflection on practice and during practice. This connection with assignments, although quite subtle and loose, colored the perceptions of the student teachers. Some viewed blogging as an assignment even though it was not required. By and large, the participants in Class B perceived academic blogs as intellectual and reflective exercises as opposed to personal blogs, which were usually of a casual and emotional nature. One interviewee remarked:

... since it's called academic blog, in my personal view, I won't post emotional blog entries to the academic blogs. We can certainly put entries like how bad a day is, how bad the class is in our personal blogs.

This also helps to explain the fewer number of emotional blog posts in Class B compared with Class A.

Another aspect of design efforts concerned the community space set up to connect dispersed individual blogs, to which the students' overall reaction was quite positive. 
Besides the messages of the instructor, the student teachers greatly valued the weekly blog summary compiled by the facilitator (77\% in Class A and $74 \%$ in Class B in agreement), and the aggregating function that brought individual blogs together (close to $70 \%$ in both classes in agreement).

\section{Discussion}

The success of academic blogging relies, to a great extent, on sustained motivation and participation of students. Our investigation into the underlying reasons for participating in academic blogs revealed a mixture of individual, social, and academic factors. The perceived values of blogs, we argue, are the crucial determinant for students' engagement. As illustrated in Figure 1, the perceived values of academic blogs can be broken down into three aspects: individual, social, and academic. The perceived individual values concern the affordances of blogs for individual-centred expressions that allow documentation of daily events and emotional outburst. The documentation of experiences, although perceived by the students as a key reason for blogging, does not appear to have been the sole purpose or theme in most of the blogs. In many cases, the recording of everyday events led to deeper reflection on teaching practice. On other occasions, social cues were present which added a social overtone to the posts. Only one student in our study sometimes showed the characteristics of selfsufficient bloggers who write blogs mostly for themselves with little or no attention to audience (see Kerawalla, Minocha, Kirkup \& Conole, 2008; Trevino, 2005). She happened to be the most active blogger in our study, with the habit of writing personal blogs as an online diary prior to this study.

\section{Perception}

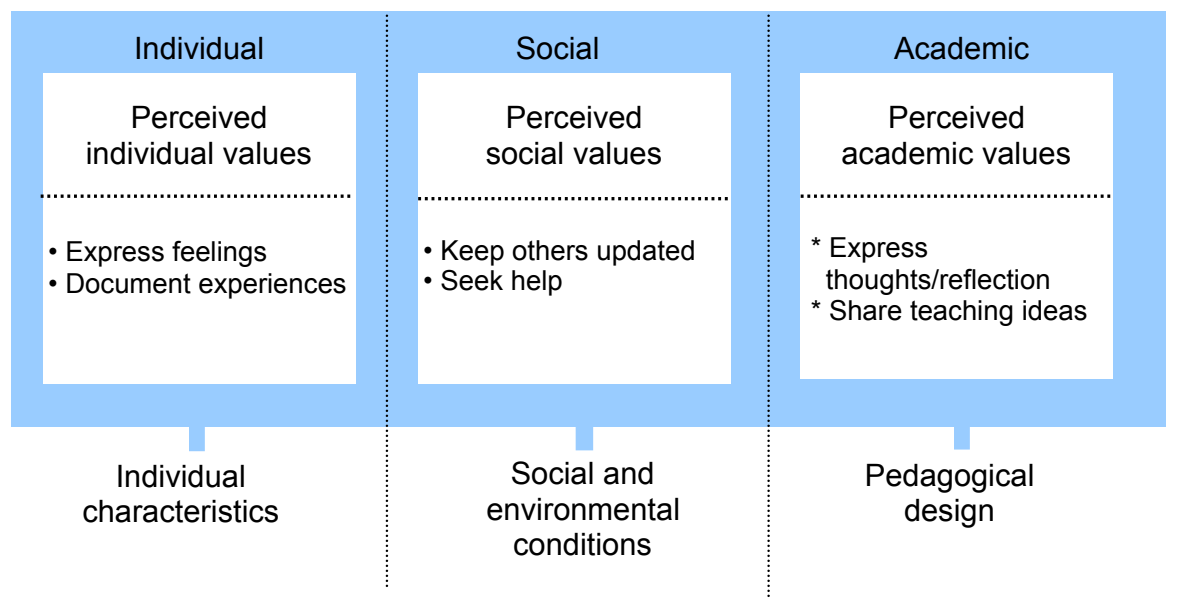

Figure 1: Perceived values of academic blogs

Although the student teachers in our study wrote blogs individually, they did not blog alone, but in a social environment. The perceived social values of academic blogging concern the affordances of blogs to keep others updated and seek help. Academic blogs are not just meant for recording daily happenings, but more importantly, for reaching out to connect with fellow students. Blogs are not just an online emotional dumping ground for students to vent. What is special about blogs is that they allow for the release of emotional tension with an audience who can provide care, social 
support, and help (Nardi, Schiano \& Gumbrecht, 2004). However, one interesting observation we made was that the student teachers seldom asked explicitly for help or sought feedback via their blogs. This might due to the asynchronous nature of blogenabled interaction that was perceived to be ill suited for problem-solving and pursuing just-in-time help (Deng \& Yuen, 2010).

With respect to the individual and social aspects mentioned above, our findings echo several previous studies such as those of Nardi, Schiano and Gumbrecht (2004) and Trevino (2005). However, what sets our study apart from the previous studies is our focus on academic blogs. Thus, the perceived academic values are singled out and highlighted. Writing academic blogs is not just for fun or for killing time: many blog posts produced by the student teachers manifest reflective thinking that constitutes the academic dimension of blogging. Anecdotes and teaching strategies captured in the blogs could serve as the source of inspiration for peers as well. As such, the perceived academic affordances of blogs for articulating thoughts and exchanging teaching ideas act as important determinant for students' blogging as well.

Other than the perceived values of blogging, there was also a set of facilitating factors that played an important role in mediating the motivation of the student teachers. First, the prior experience and habit of individual students regarding blogging determined their readiness for academic blogging. Those who already had the habit of sharing their daily life and thoughts in personal blogs seemed likely to embrace academic blogs. Second, the social and environmental conditions could also affect the level of engagement in academic blogging. Since the students in the two classes were already well acquainted with each other, there was a strong sense of community and social relationships among classmates, which served as an effective catalyst for writing blogs to share and communicate with one another. In this respect, our findings support the idea that the pre-existing social liaison can provide an impetus for online engagement (Kavanaugh, Carroll, Rosson, Zin \& Reese, 2005). At the same time, the social resources available in one's immediate physical environment can encourage the adoption of academic blogging. For those students who were not familiar with blogging, a fellow student who was able and willing to provide help and support could be a valuable resource. On the other hand, lack of social support in one's physical context could serve as a strong impetus for using blogging as an alternative outlet for emotional release and reaching out for support. In this respect, our findings are in line with previous studies that show that inadequate social support available in real life engenders increased motivation and engagement with online groups (Turner, Grube \& Meyers, 2001).

The third facilitating factor pertains to pedagogical design, which is also unique to academic blogging. This study shows how teachers design academic blogging activities can influence the degree of students' engagement with academic blogging, as well as their blog style and content. In our study, although blogging was voluntary and loosely connected with assignments, the visibility of their blogs to the instructor as well as to fellow students served as an effective impetus for blogging, for at least some students. The encouragement of the instructor was not perceived as a strong motivator, but many student teachers would still appreciate more online teaching presence. The presence of teachers online is regarded by many scholars (e.g. Bullen, 1998; Wu \& Hiltz, 2004) as crucial for successful online discussions or learning. The participation of experienced teachers in online discussions can provide valuable assistance to novice teachers, helping them to expand their insights and achieve a deeper level of reflection 
(Whipp, 2003). It can be argued the students' engagement with academic blogging might be enhanced if the instructor could be more active in posting and responding to students' blogs. In addition, the online community space played an important role in enhancing a sense of togetherness and many of its features, such as the instructor's messages and weekly blog summary, were greatly appreciated.

\section{Conclusion and implications}

In a blog-supported learning community, it is vital to mobilise the agency of individual students as content creators. Our investigation into what motivated student teachers to engage in academic blogging yielded a complex picture of individual, social, and academic factors. This study can contribute to an important yet neglected area of educational blogging - the motivation and perceptions of students. The results have revealed a number of factors such as students' perceptions, social conditions, and pedagogical design that teachers should take into account when designing a blogsupported online environment. Our study can have methodological implications for other studies in the field as well. It shows that content analysis might be a useful way to reveal the underlying purposes of writing blogs, and can thus be used more often in future studies on the theme.

More importantly, our findings give rise to some practical implications for promoting and sustaining students' motivation, which are especially relevant to teacher educators. To jump-start academic blogging, efforts should be made to identify students who have the potential to become self-driven and recruit them as early adopters or core members. Students who are active in writing personal blogs or participating in online asynchronous discussion can be good candidates since they are plausibly comfortable with online communications, or are equipped with an innate desire to express themselves online. At the same time, caution should be exercised when recruiting self-sustained bloggers since such bloggers could, just as easily, be the type of blogger who only writes for himself/herself. The writing-for-self type of entries could dilute the overall quality of academic blogs since they tend to be short or superficial.

Second, teachers should endeavour to mobilise the existing social capital and channel the bonds among partnered students into positive energy. If student teachers are sent to placement schools in pairs or groups, care should be taken to team up students with no or little blogging experience with those who are more technologically competent. As such, students are more likely to overcome the technological barrier when technical and social support is readily available. Once students start blogging, they should be encouraged to promote their blogs through their own social networks. For example, they can post a link to blog on Facebook and invite their friends and peer students to visit and leave comments.

When the motivators with respect to the individual and/or social dimensions are not strong enough, more efforts should be made to create extraneous incentive through pedagogical design. A teacher or an online facilitator should be present online to maintain students' motivation, provide feedback, encourage students to think deeper, and engage them more as active participants. When the course instructor can not fulfill such role, an online facilitator should be appointed. Alternatively, assigning roles to the students, letting them take turns acting as online facilitators, can be another way to stimulate their interest and instill a sense of ownership. 


\section{Acknowledgment}

We would like to thank Dr Cheri Chan for her enthusiasm, support, and constructive feedback throughout the study.

\section{References}

Blood, R. (2002). The weblog handbook: Practical advice on creating and maintaining your blog. Cambridge, Mass.: Perseus Books Group.

Brescia, W. F. Jr. \& Miller, M. T. (2006). What's it worth? The perceived benefits of instructional blogging. Electronic Journal for the Integration of Technology in Education, 5, 44-52. http: / / ejite.isu.edu/Volume5/Brescia.pdf

Brown, J. S. \& Adler, R. P. (2008). Minds on fire: Open education, the long tail, and learning 2.0. Educause Review, 43(1), 16-32. http: / / www.educause.edu / EDUCAUSE+Review / EDU CAUSEReviewMagazineVolume43/MindsonFireOpenEducationtheLon/162420

Bullen, M. (1998). Participation and critical thinking in online university distance education. Journal of Distance Education, 13(2), 1-32. http: / / www.jofde.ca/index.php/jde/article/view/140/394

Creswell, J. W. (2009). Research design: Qualitative, quantitative, and mixed methods approaches (3rd ed.). Thousand Oaks, CA: Sage Publications.

Davis, F. D. (1989). Perceived usefulness, perceived ease of use, and user acceptance of information technology. MIS Quarterly, 13(3), 319-340. http: / / misq.org/ perceivedusefulness-perceived-ease-of-use-and-user-acceptance-of-informationtechnology.html?SID=3mt4ddousnf19eklt62umnqjt4

Davies, J. \& Merchant, G. (2009). Web 2.0 for schools: Learning and social participation. New York: Peter Lang.

Deng, L. \& Yuen, H. K. (2010). Exploring the role of academic blogs in a blended community: An integrative approach. Research and Practice in Technology Enhanced Learning, 5(2), 53-71. http: / / apsce.net/ RPTEL/2010_05_02_1.pdf

Deng, L. \& Yuen, H. K. (2011). Towards a framework for educational affordances of blogs. Computers \& Education, 56(2), 441-451. http:/ / dx.doi.org/10.1016/j.compedu.2010.09.005

Dickey, M. D. (2004). The impact of web-logs (blogs) on student perceptions of isolation and alienation in a web-based distance-learning environment. Open Learning, 19(3), 279-291. http: / / dx.doi.org/10.1080/0268051042000280138

Du, H. S. \& Wagner, C. (2007). Learning with weblogs: Enhancing cognitive and social knowledge construction. IEEE Transactions on Professional Communication, 50(1), 1-16. http: / / dx.doi.org/10.1109/ TPC.2006.890848

Ducate, L. C. \& Lomicka, L. L. (2008). Adventures in the blogosphere: From blog readers to blog writers. Computer Assisted Language Learning, 21(1), 9-28. http: / / dx.doi.org/10.1080/09588220701865474

Ekdale, B., Namkoong, K., Fung, T. K. F. \& Perlmutter, D. D. (2010). Why blog? (then and now): Exploring the motivations for blogging by popular American political bloggers. New Media E Society, 12(2), 217-234. http:/ / dx.doi.org/10.1177 / 1461444809341440

Ferdig, R. E. \& Trammell, K. D. (2004). Content delivery in the 'Blogosphere'. THE Journal, 31(7), 12-16. http:/ / thejournal.com/articles / 2004/02 / 01/ content-delivery-in-theblogosphere.aspx?sc_lang=en

Guadagno, R. E., Okdie, B. M. \& Eno, C. A. (2008). Who blogs? Personality predictors of blogging. Computers in Human Behavior, 24(5), 1993-2004.

http:/ / dx.doi.org/10.1016/j.chb.2007.09.001 
Hall, H. \& Davison, B. (2007). Social software as support in hybrid learning environments: The value of the blog as a tool for reflective learning and peer support. Library and Information Science Research, 29(2), 163-187. http: / / dx.doi.org/10.1016/j.lisr.2007.04.007

Hamuy, E. \& Galaz, M. (2010). Information versus communication in Course Management System participation. Computers $\mathcal{E}$ Education, 54(1), 169-177. http: / / dx.doi.org/10.1016/j.compedu.2009.08.001

Harrison, T. M. \& Barthel, B. (2009). Wielding new media in Web 2.0: Exploring the history of engagement with the collaborative construction of media products. New Media $\mathcal{E}$ Society, 11(1-2), 155-178. http: / / dx.doi.org/10.1177/1461444808099580

Hatton, N. \& Smith, D. (1995). Reflection in teacher education: Towards definition and implementation. Teaching and Teacher Education, 11(1), 33-49. http: / / dx.doi.org/ 10.1016/0742-051X(94)00012-U

Hernández-Ramos, P. (2004). Web logs and online discussions as tools to promote reflective practice. The Journal of Interactive Online Learning, 3(1). http: / / www.ncolr.org/jiol/issues/pdf/3.1.4.pdf

Herring, S. C., Scheidt, L. A., Wright, E. \& Bonus, S. (2005). Weblogs as a bridging genre. Information Technology \& People, 18(2), 142-171. http: / / dx.doi.org/10.1108/09593840510601513

Hollenbaugh, E. E. (2011). Motives for maintaining personal journal blogs. CyberPsychology, Behavior, and Social Networking, 14(1-2), 13-20. http:/ / dx.doi.org/10.1089/ cyber.2009.0403

Hourigan, T., \& Murray, L. (2010). Using blogs to help language students to develop reflective learning strategies: Towards a pedagogical framework. Australasian Journal of Educational Technology, 26(2), 209-225. http:/ / www.ascilite.org.au/ajet/ ajet26/hourigan.html

Hsu, C. L. \& Lin, J. C. C. (2008). Acceptance of blog usage: The roles of technology acceptance, social influence and knowledge sharing motivation. Information $\mathcal{E}$ Management, 45(1), 65-74. http: / / dx.doi.org/10.1016/j.im.2007.11.001

Jenkins, H. (2006). Convergence culture: Where old and new media collide. New York: New York University Press.

Kavanaugh, A., Carroll, J. M., Rosson, M. B., Zin, T. T. \& Reese, D. D. (2005). Community networks: Where offline communities meet online. Journal of Computer-Mediated Communication, 10(4). Retrieved July 4, 2007 from http: / / jcmc.indiana.edu/vol10/issue4/kavanaugh.html

Kerawalla, L., Minocha, S., Kirkup, G. \& Conole, G. (2008). Characterising the different blogging behaviours of students on an online distance learning course. Learning, Media and Technology, 33(1), 21-33. http: / / dx.doi.org/10.1080/17439880701868838

Kerawalla, L., Minocha, S., Kirkup, G. \& Conole, G. (2009). An empirically grounded framework to guide blogging in higher education. Journal of Computer Assisted Learning, 25(1), 31-42. http: / / dx.doi.org/10.1111/j.1365-2729.2008.00286.x

Kirschner, P. A. (2002). Can we support CSCL? Educational, social and technological affordances. In P. Kirschner (Ed.), Three worlds of CSCL: Can we support CSCL? (pp. 7-47). Heerlen: Open University of the Netherlands. http: / / igitur-archive.library.uu.nl/fss / 2008-0108212846/kirschner_02_threeworldcscl.pdf

Korthagen, F. \& Vasalos, A. (2005). Levels in reflection: Core reflection as a means to enhance professional growth. Teachers and Teaching, 11(1), 47-71. http: / / dx.doi.org/ 10.1080/ 1354060042000337093

Loving, C. C., Schroeder, C., Kang, R., Shimek, C. \& Herbert, B. (2007). Blogs: Enhancing links in a professional learning community of science and mathematics teachers. Contemporary Issues in Technology and Teacher Education, 7(3), 178-198. http: / / www.editlib.org/p/24373 
Luehmann, A. L. \& Tinelli, L. (2008). Teacher professional identity development with social networking technologies: Learning reform through blogging. Educational Media International, 45(4), 323-333. http: / / dx.doi.org/10.1080/09523980802573263

McLoughlin, C. \& Lee, M. (2007). Social software and participatory learning: Pedagogical choices with technology affordances in the Web 2.0 era. In ICT: Providing choices for learners and learning. Proceedings ascilite Singapore 2007.

http: / / www.ascilite.org.au/conferences/singapore07/procs/mcloughlin.pdf

Miura, A. \& Yamashita, K. (2007). Psychological and social influences on blog writing: An online survey of blog authors in Japan. Journal of Computer Mediated Communication, 12(4), 14521471. http:/ / jcmc.indiana.edu/vol12/issue4/ miura.html

Mompean, A. R. (2010). The development of meaningful interactions on a blog used for the learning of English as a foreign language. ReCALL, 22(03), 376-395. http: / / dx.doi.org/ 10.1017/ S0958344010000200

Morgan, G. (2003). Faculty use of course management systems. Educause Center for Applied Research. http: / / net.educause.edu/ir/library/pdf/ERS0302/ekf0302.pdf

Nardi, B. A., Schiano, D. J. \& Gumbrecht, M. (2004). Blogging as social activity, or, would you let 900 million people read your diary? In Proceedings of the 2004 ACM conference on Computer supported cooperative work (pp. 222-231). http: / / dx.doi.org/10.1145/1031607.1031643

Nardi, B. A., Shiano, D. J., Gumbrecht, M. \& Swartz, L. (2004). Why we blog. Communications of the ACM, 47(12), 41-46. http:/ / dx.doi.org/10.1145/1035134.1035163

O'Reilly, T. (2007). What is Web 2.0: Design patterns and business models for the next generation of software. Communications $\mathcal{E}$ Strategies, 65(Jan), 17-37. http: / / www.oreillynet.com/lpt/a / 6228

Ray, B. B. \& Coulter, G. A. (2008). Reflective practices among language arts teachers: The use of weblogs. Contemporary Issues in Technology and Teacher Education, 8(1), 6-26. http:/ / www.citejournal.org/vol8/iss1/languagearts/article1.cfm

Ray, B. B. \& Hocutt, M. M. (2006). Teacher-created, teacher-centered weblogs: Perceptions and practices. Journal of Computing in Teacher Education, 23(1), 11-18. http: / / www.iste.org/Store/Product.aspx?ID=1407

Rourke, L., Anderson, T., Garrison, D. R. \& Archer, W. (1999). Assessing social presence in asynchronous text-based computer conferencing. Journal of Distance Education, 14(2), 50-71. http: / / www.jofde.ca/index.php/jde/article/ view/153/341

Stefanac, S. (2006). Dispatches from Blogistan: A travel guide for the modern blogger. Berkeley, CA: New Riders.

Stefanone, M. A. \& Jang, C. (2007). Writing for friends and family: The interpersonal nature of blogs. Journal of Computer-Mediated Communication, 13(1). http: / / jcmc.indiana.edu/vol13/issue1/stefanone.html

Stiler, G. M. \& Philleo, T. (2003). Blogging and blogspots: An alternative format for encouraging reflective practice among preservice teachers. Education, 123(4), 789-798. http:/ / www.docstoc. $\mathrm{com} /$ docs $/ 55300818$ / Blogging-and-blogspots-an-alternative-format-for-encouraging-reflectivepractice-among-preservice-teachers(Blogger-an-online-weblog-service-for-student-teachers)

Surbeck, E., Han, E. P. \& Moyer, J. E. (1991). Assessing reflective responses in journals. Educational Leadership, 48(6), 25-27. [verified 4 Jan 2012] http: / / www.ascd.org/ASCD / pdf/journals / ed_lead/el_199103_surbeck.pdf

Trevino, E. M. (2005). Blogger motivations: Power, pull, and positive feedback. In Internet Research 6.0. Chicago: Association of Internet Researchers.

Turner, J. W., Grube, J. A. \& Meyers, J. (2001). Developing an optimal match within online communities: An exploration of CMC support communities and traditional support. Journal of Communication, 51(2), 231-251. http: / / dx.doi.org/10.1111/j.1460-2466.2001.tb02879.x 
Wakefield, J. F. (1996). Educational psychology: Learning to be a problem solver. Boston: Houghton Mifflin.

Wang, Y., Lin, H. \& Liao, Y. (2012). Investigating the individual difference antecedents of perceived enjoyment in students' use of blogging. British Journal of Educational Technology, 43(1), 139-152. http: / / dx.doi.org/10.1111/j.1467-8535.2010.01151.x

Whipp, J. L. (2003). Scaffolding critical reflection in online discussions: Helping prospective teachers think deeply about field experiences in urban schools. Journal of Teacher Education, 54(4), 321-333. http: / / dx.doi.org/10.1177/ 0022487103255010

Williams, J. B. \& Jacobs, J. (2004). Exploring the use of blogs as learning spaces in the higher education sector. Australasian Journal of Educational Technology, 20(2), 232-247. http: / / www.ascilite.org.au / ajet/ajet20/ williams.html

Wopereis, I. G., Sloep, P. B. \& Poortman, S. H. (2010). Weblogs as instruments for reflection on action in teacher education. Interactive Learning Environments, 18(3), 245-261. http: / / dx.doi.org/ 10.1080/10494820.2010.500530

Wortham, J. (2007). After 10 years of blogs, the future's brighter than ever. Wired. http: / / www.wired.com/entertainment/theweb/news/2007/12/blog_anniversary

Wu, D. \& Hiltz, S. R. (2004). Predicting learning from asynchronous online discussions. Journal of Asynchronous Learning Networks, 8(2), 139-152.

http: / / sloanconsortium.org/sites/default/files/v8n2_wu_1.pdf

Xie, Y. \& Sharma, P. (2005). Students' lived experience of using weblogs in a class: An exploratory study. Presented at the Annual meeting of the Association for Educational Communications and Technology, Chicago. http:/ / www.eric.ed.gov/PDFS/ED485009.pdf

Yang, S. H. (2009). Using blogs to enhance critical reflection and community of practice. Educational Technology \& Society, 12(2), 11-21. http:/ / www.ifets.info/journals/12_2/2.pdf

Zastrocky, M., Harris, M. \& Lowendahl, J. (2008). E-Learning for higher education: Are we reaching maturity? http: / / www.gartner.com/DisplayDocument?id=633416

\section{Appendix: Questionnaire on the use of blogs during TP}

The questionnaire has been edited to include only the sections that are relevant for this article.

This questionnaire aims to understand your experience and perceptions of academic blogs during Teaching Practice. Your genuine feedback will provide valuable data on using technology to support reflection and peer sharing in the future.

Please choose your level of agreement with the following statements

\begin{tabular}{|c|c|c|c|ccc|}
\hline $\begin{array}{c}\text { Strongly agree } \\
\text { (SA) }\end{array}$ & $\begin{array}{c}\text { Agree } \\
\text { (A) }\end{array}$ & $\begin{array}{c}\text { Not sure } \\
\text { (N) }\end{array}$ & \multicolumn{2}{c|}{$\begin{array}{c}\text { Disagree } \\
\text { (D) }\end{array}$} & \multicolumn{2}{c|}{$\begin{array}{c}\text { Strongly disagree } \\
\text { (SD) }\end{array}$} \\
\hline 5 & 4 & 3 & 2 & & \multicolumn{2}{c|}{1} \\
\hline
\end{tabular}

Others: 
2. Academic blogs are helpful in Enabling self-expressions

Enabling self-reflection

Recording my TP experience

Enabling exchange of teaching ideas

Enabling exchange of social support

$\begin{array}{ccccc}\text { SA } & \text { A } & \text { N } & \text { D } & \text { SD } \\ 5 & 4 & 3 & 2 & 1 \\ 5 & 4 & 3 & 2 & 1 \\ 5 & 4 & 3 & 2 & 1 \\ 5 & 4 & 3 & 2 & 1 \\ 5 & 4 & 3 & 2 & 1\end{array}$

Others:

3. The following factors influenced my interest in blogging

Lack of time

Limited access to computer and Internet

I am not comfortable with technology

I am not sure what to write about in my blogs

I prefer to write my own personal blogs or journals

The academic blogs were not assessed

Not many classmates wrote academic blogs

I prefer to use other media for peer sharing

I had enough peer sharing and support at placement school

$\begin{array}{ccccc}\text { SA } & \text { A } & \text { N } & \text { D } & \text { SD } \\ 5 & 4 & 3 & 2 & 1 \\ 5 & 4 & 3 & 2 & 1 \\ 5 & 4 & 3 & 2 & 1 \\ 5 & 4 & 3 & 2 & 1 \\ 5 & 4 & 3 & 2 & 1 \\ 5 & 4 & 3 & 2 & 1 \\ 5 & 4 & 3 & 2 & 1 \\ 5 & 4 & 3 & 2 & 1 \\ 5 & 4 & 3 & 2 & 1\end{array}$

Others :

4. I might be more motivated to write academic blogs

If the tutor gave me comments

If more classmates participated

If I could get more comments from peers

If the academic blogs were assessed

$\begin{array}{ccccc}\text { SA } & \text { A } & \text { N } & \text { D } & \text { SD } \\ 5 & 4 & 3 & 2 & 1 \\ 5 & 4 & 3 & 2 & 1 \\ 5 & 4 & 3 & 2 & 1 \\ 5 & 4 & 3 & 2 & 1\end{array}$

Others :

5. I find these features of community space useful: Weekly summary of blogs and email reminders

Messages from the tutor

Discussions on community space

Links to peers' blogs

Lesson plans shared by other classmates

$\begin{array}{ccccc}\text { SA } & \text { A } & \text { N } & \text { D } & \text { SD } \\ 5 & 4 & 3 & 2 & 1 \\ 5 & 4 & 3 & 2 & 1 \\ 5 & 4 & 3 & 2 & 1 \\ 5 & 4 & 3 & 2 & 1 \\ 5 & 4 & 3 & 2 & 1\end{array}$

Authors: Dr Liping Deng

Department of Education Studies, Hong Kong Baptist University

Kowloon Tong, Hong Kong

Email: liping@graduate.hku.hk

Associate Professor Allan H. K. Yuen

Room 214, Runme Shaw Building

Faculty of Education, The University of Hong Kong

Email: hkyuen@hkucc.hku.hk Web: http:/ / people.cite.hku.hk/hkyuen/

Please cite as: Deng, L. \& Yuen, H. K. (2011). Understanding student perceptions and motivation towards academic blogs: An exploratory study. Australasian Journal of Educational Technology, 28(1), 48-66. http: / / www.ascilite.org.au/ajet/ajet28/ deng.html 